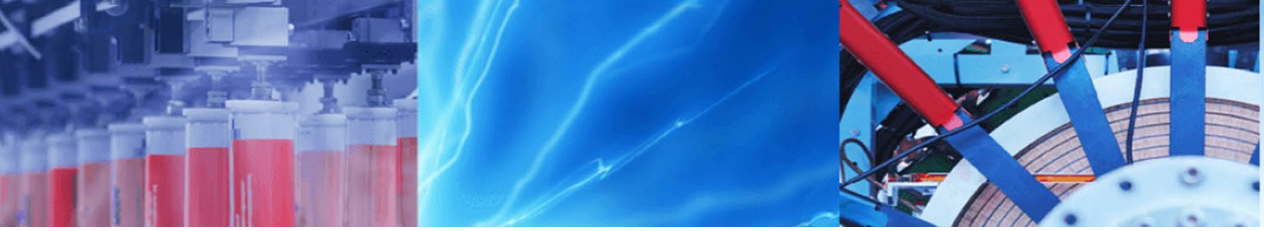

Research Article

\title{
Biodiesel synthesis from palm fatty acid distillate using enzyme immobilized on magnetic nanoparticles
}

\author{
Anilkumar R. Gupta ${ }^{1} \cdot$ Virendra K. Rathod $^{1}$ (i)
}

Received: 20 April 2020 / Accepted: 13 August 2020 / Published online: 6 October 2020

(c) Springer Nature Switzerland AG 2020

\begin{abstract}
The present study deals with the esterification of palm fatty acid distillate (PFAD) using immobilized lipase on magnetic nanoparticles (MNPs) to produce biodiesel in a cleaner and more environmentally friendly way. Commercially available lipase $C A L B_{E X}$ was used for immobilization of lipase on MNPs. The effect of various reaction parameters including the methanol-to-PFAD molar ratio, biocatalyst loading, reaction temperature, and agitation speed was examined using a one-factor-at-a-time approach. Maximum PFAD conversion of $82.74 \%$ was achieved under mild reaction conditions, with a methanol-to-PFAD molar ratio of $1.6: 1$, biocatalyst loading of $8 \mathrm{wt} \%$ (lipase content $0.45 \mathrm{wt} \%$ ), agitation speed of $150 \mathrm{rpm}$, reaction temperature of $50^{\circ} \mathrm{C}$, and reaction time of $10 \mathrm{~h}$. The catalytic activity of MNP-CALB $\mathrm{EX}_{\text {Was compared }}$ with commercial Amberlyst-15 under similar reaction conditions. It was observed that MNP-CALB EX $_{\text {achieved 2.6-fold }}$ higher conversion than Amberlyst-15. The reusability of the immobilized biocatalyst was also tested to determine cost feasibility. It was observed that the immobilized biocatalyst could be used up to five cycles, with residual conversion of $80.19 \%$ in the fifth cycle.
\end{abstract}

Keywords FAME PFAD Enzyme $\cdot$ Immobilization · Magnetic nanoparticles

\section{Introduction}

Energy consumption has increased globally due to population explosion and industrialization, resulting in a serious energy crisis [1]. In the current scenario, the energy required in the transport sector is supplied by conventional fossil fuels like petroleum and natural gas [2]. Fossil fuels are non-renewable energy sources, and are the primary source of greenhouse gas emissions in the environment [3]. Also, the continuous hike in the price of the limited stock of fossil fuel has caused policymakers to consider alternative options such as biodiesel and bioethanol, especially in developing countries like India [4]. India ranked third in the world after the USA and China in oil consumption in 2018 [5]. Moreover, there is a huge gap between domestic crude oil production and consumption.
India's crude oil production has declined continuously over the past 7 years (2012-2018), with dependence on imports rising to $84 \%$ [6]. India spent Rs 4.7 lakh crore, or USD 70.196 billion, on crude oil imports in 2016-2017 [7]. However, biofuel can be used to replace a percentage of liquid fossil fuel, which can help in reducing the massive outflow of foreign currency [8]. In this context, the Ministry of Petroleum and Natural Gas, Government of India, approved a national policy on biofuel in 2018, targeting a $5 \%$ blend of biodiesel in diesel and $20 \%$ blend in ethanol in petrol by 2030 [9].

Biodiesel or fatty acid methyl ester (FAME) is a renewable and biodegradable fuel alternative to petroleum diesel. It can be produced from the transesterification of edible oils such as sunflower, palm, soybean, or corn oil, from esterification followed by transesterification of non-edible

$\triangle$ Virendra K. Rathod, vk.rathod@ictmumbai.edu.in | ${ }^{1}$ Department of Chemical Engineering, Institute of Chemical Technology, Matunga (E), Mumbai 400019, India. 
oils such as Jatropha curcas, Pongamia pinnata (karanja oil), linseed, Azadirachta indica (neem oil), or Ricinus communis (castor oil), or by esterification of palm fatty acid distillate [10] with short-chain alcohols (methanol or ethanol) [11]. The production of biodiesel from edible oil is not economically viable, as it not only increases production costs but also competes with food production, leading to major nutritional and ethical concerns [12]. Therefore, cheap, non-edible, and readily available feedstocks can solve the problems associated with edible oil. Palm fatty acid distillate (PFAD) is a cheap and readily available feedstock (INR 10-30/kg) for biodiesel production, as it is formed as a residue during the palm oil refining process [13]. PFAD contains about $93 \%$ free fatty acids (FFA), and requires acid catalysts to carry out the esterification reaction [14].

Sulfuric acid is commonly used as a catalyst for the transformation of PFAD to FAME. However, due to the corrosive nature of sulfuric acid, costly equipment is required for handling, which results in higher production costs. Additionally, after completion of the reaction, a neutralization process must be carried out, which generates a large quantity of wastewater. Therefore, many studies in the literature have reported the use of a heterogeneous acid catalyst $\left(\mathrm{CM}-\mathrm{SO}_{3} \mathrm{H}\right.$, sulfonated graphene, sulfated $\mathrm{LaO}$ ) as a suitable candidate to promote the esterification reaction [15-17]. Though heterogeneous acid catalysts are a better alternative to homogeneous acid catalysts, the reaction conditions are comparatively harsh, requiring high temperature and a large amount of methanol (MeOH). Hence, research scientists have investigated the use of lipase as biocatalyst, which can be performed under very mild reaction conditions [18].

Furthermore, lipase can esterify/transesterify a wide variety of edible and non-edible feedstocks, irrespective of the presence of FFA and some amount of water, and also produces a pure and high-quality product (biodiesel), with glycerol as by-product [19]. Lipase-catalyzed biodiesel production is a greener, cleaner, and safer process. However, the use of lipase in free form is not cost-effective. Consequently, different techniques have been developed to immobilize lipase so that it can be recycled to reduce biodiesel production costs. Babaki et al. [20] immobilized lipase on silica nanoparticles for the transesterification of canola oil.

Similarly, Macario et al. [21] synthesized lipaseencapsulated silica nanoparticles for the transesterification of triolein to produce biodiesel. In another study, Miao et al. [22] prepared a biocatalyst by immobilization of lipase on amino-functionalized magnetic nanoparticles (MNPs). The prepared catalyst was tested for FAME synthesis from rapeseed oil. The authors reported maximum conversion of $89.4 \%$ under optimal reaction conditions, i.e., molar ratio of $6: 1$, catalyst loading of 20 wt $\%$, water content of $2 \%$, temperature of $45^{\circ} \mathrm{C}$, and agitation speed of $250 \mathrm{rpm}$ over a reaction period of $24 \mathrm{~h}$. Xie and Wang [23] also immobilized lipase on magnetic $\mathrm{Fe}_{3} \mathrm{O}_{4} /$ poly(styrene-methacrylic acid) microspheres for the transesterification of soybean oil.

However, a detailed review of the literature revealed no published work on the esterification of PFAD using lipase immobilized on $\mathrm{Fe}_{3} \mathrm{O}_{4}-\mathrm{NH}_{2}$ magnetic nanoparticles. Therefore, the present work is focused on the detailed study of esterification of PFAD in the presence of a biocatalyst in the form of immobilized lipase on $\mathrm{Fe}_{3} \mathrm{O}_{4}$ magnetic nanoparticles for biodiesel synthesis. The immobilized biocatalyst was characterized by Fourier transform infrared spectroscopy (FTIR), transmission electron microscopy TEM, and Brunauer-Emmett-Teller (BET) analysis. The influence of various reaction conditions including PFAD-to-methanol molar ratio, biocatalyst loading, reaction temperature, and agitation speed was also examined.

\section{Materials and methods}

\subsection{Materials}

PFAD was procured from Godrej Industries Ltd. (Mumbai, India). The fatty acid composition and properties of the PFAD are presented in Table 1, and are similar to our previous work [1]. Ferrous sulfate $\left(\mathrm{FeSO}_{4} .7 \mathrm{H}_{2} \mathrm{O}\right)$, ferric chloride $(\mathrm{FeCl} 3), 25 \%$ ammonia solution, ethanol, methanol $(\mathrm{MeOH})$, glutaraldehyde, potassium hydroxide $(\mathrm{KOH})$, isopropanol, gum arabic, p-nitrophenyl acetate (pNPA), chloroform, and isoamyl alcohol were all AR grade and purchased from SD Fine-Chem Ltd., Mumbai. The free

Table 1 Fatty acid composition and properties of PFAD

\begin{tabular}{lc}
\hline PFAD & Value \\
\hline Fatty acid composition & \\
Palmitic acid (\%) & 49.6 \\
Stearic acid (\%) & 4.7 \\
Oleic acid (\%) & 35.3 \\
Linoleic acid (\%) & 9.1 \\
Others (\%) & 1.3 \\
Properties & \\
Saponification value (mg of $\mathrm{KOH} / \mathrm{g}$ of PFAD) & 198.2 \\
Acid value (mg of KOH/g of PFAD - & 186.1 \\
AOCS Te 2a-64) & 38.4 \\
Viscosity (mm $\left.{ }^{2} / \mathrm{s}\right)$ & 0.919 \\
Density (g/cm ${ }^{3}$ ) & 0.14 \\
Water content (\%) & 267.9 \\
Molecular weight (g/mol) & \\
\hline
\end{tabular}


enzyme Candida antarctica lipase B (CALB $\mathrm{EX}_{10,000)}$ was kindly donated by Fermenta Biotech Ltd. (Thane, India). The methyl esters including methyl palmitate, methyl oleate, methyl stearate, and methyl linoleate of HPLC grade were procured from Sigma-Aldrich.

\subsection{Methods}

\subsubsection{Lipase activity assay}

Lipase activity was measured spectrophotometrically by hydrolysis of $p$-nitrophenyl acetate (pNPA) to p-nitrophenol ( $p N P$ ) at $405 \mathrm{~nm}$ using a UV-Vis spectrophotometer (Jasco, USA) [24]. Briefly, $0.1 \mathrm{~mL}$ of $0.1 \mathrm{M}$ pNPA (prepared in isopropanol) was added to $1.9 \mathrm{~mL}$ of buffer solution ( $0.1 \mathrm{M}$ sodium phosphate $\mathrm{pH}$ 7.0) and heated to $40^{\circ} \mathrm{C}$. When the temperature reached to $40^{\circ} \mathrm{C}$, lipase was added and the mixture was incubated for $5 \mathrm{~min}$. After incubation, $2 \mathrm{~mL}$ of Marmur solution (chloroform:Isoamyl alcohol 24:1) was added to stop the reaction. Centrifugation of the mixture was then carried out at $8000 \mathrm{rpm}$ for $3 \mathrm{~min}$ at $4{ }^{\circ} \mathrm{C}$. The bright yellowish solution ( $p$-nitrophenol) from the top was extracted to determine the enzyme activity. One unit (U) of enzyme activity is defined as $\mu \mathrm{mol}$ of pNPA transformed into pNP per min during hydrolysis at optimal conditions. Lipase activity was found to be $8.56 \mathrm{U} \mathrm{mg}^{-1}$.

\subsubsection{Catalyst preparation}

The catalyst was synthesized in two steps, as previously reported [25]. Firstly, $\mathrm{FeSO}_{4} \cdot 7 \mathrm{H}_{2} \mathrm{O}$ and $\mathrm{FeCl}_{3}$ in a 2:1 molar ratio were added to distilled water at room temperature $\left(34{ }^{\circ} \mathrm{C}\right.$ ) under continuous nitrogen gas purging to avoid probable oxidation. Once the $\mathrm{FeSO}_{4} \cdot 7 \mathrm{H}_{2} \mathrm{O}$ and $\mathrm{FeCl}_{3}$ mixture was completely dissolved, aqueous ammonia solution was added dropwise under vigorous stirring until the $\mathrm{pH}$ of the solution reached to 10 . At this $\mathrm{pH}, \mathrm{Fe}_{3} \mathrm{O}_{4}$ was precipitated out and separated using a magnet. The isolated precipitate was lyophilized for $48 \mathrm{~h}$ under vacuum to obtain amine-functionalized $\mathrm{Fe}_{3} \mathrm{O}_{4}$ magnetic nanoparticles.

In the second step, the immobilization of $C_{A L B}$ 10,000 on amine-functionalized $\mathrm{Fe}_{3} \mathrm{O}_{4}$ magnetic nanoparticles was performed. Firstly, $750 \mathrm{mg}$ of $\mathrm{Fe}_{3} \mathrm{O}_{4}-\mathrm{NH}_{2}$ nanoparticles was dispersed in $5 \mathrm{~mL}$ of deionized water by sonication. The dispersed $\mathrm{Fe}_{3} \mathrm{O}_{4}-\mathrm{NH}_{2}$ nanoparticles were mixed with $5 \mathrm{~mL} \mathrm{CALB} \mathrm{EX}_{10,000}$ (10 $\mathrm{mg} / \mathrm{mL}$ in phosphate buffer solution), and then $1 \mathrm{~mL}$ of $25 \%$ glutaraldehyde solution was added to the mixture. This mixture was incubated at $30^{\circ} \mathrm{C}$ in an orbital shaker at $150 \mathrm{rpm}$ for $50 \mathrm{~min}$. After incubation, immobilized magnetic nanoparticles were separated from the supernatant by a magnet and washed five to six times with distilled water and air-dried. The synthesized nanocatalyst was labeled MNP-CALB ${ }_{E X}$. The percent activity recovery of lipase in immobilized form was determined from Eq. 1.

Activity recovery $(\%)=\frac{\text { The activity of immobilized lipase }}{\text { The activity of free lipase }} \times 100$

\subsubsection{Immobilization efficiency}

Immobilization efficiency is defined as the ratio of the amount of enzyme $\left(C A L B_{E X} 10,000\right)$ immobilized to the total amount of the enzyme used [26], as given in Eq. 2. The amount of enzyme immobilized is the difference between the initial enzyme concentration and the nonimmobilized enzyme concentration found in the supernatant. The protein concentration in the supernatant was evaluated by the Bradford assay, as described elsewhere [27].

$$
\begin{aligned}
& \text { Immobilization efficiency (\%) } \\
& =\frac{\text { Amount of enzyme immobilized to } \mathrm{Fe}_{3} \mathrm{O}_{4}-\mathrm{NH}_{2}}{\text { Amount of enzyme used }} \times 100
\end{aligned}
$$

\subsubsection{Catalyst characterization}

The Fourier transform infrared (FT-IR) spectra of MNP-CAL$B_{E X}, C A L B_{E X}$ and $M N P-N_{2}$ were recorded on an IRAffinity-1 FTIR spectrometer. TEM images of MNP-CALB $B_{E X}$ were acquired using a JEOL JEM-2100 instrument. The specific surface area of MNP-CALB ${ }_{E X}$ was obtained using a BET sorptometer (Porous Materials Inc., USA).

\subsubsection{Reaction procedure for the esterification of PFAD using MNP-CALB ${ }_{E X}$}

The esterification reaction of PFAD was performed in a $20 \mathrm{~mL}$ baffled glass reactor with a three-neck lid fitted with a stirrer, reflux glass condenser, and thermometer. Firstly, a known amount of PFAD was added to the glass reactor and heated at $45^{\circ} \mathrm{C}$ with the help of a thermostatic water bath to convert solid PFAD into liquid. After liquefaction, a pre-calculated quantity of $\mathrm{MeOH}$ and immobilized lipase (MNP-CALB $B_{E X}$ ) was added to start the reaction. Aliquots from the esterified reaction mixture were taken off at a fixed interval of time and analyzed with standard acid value and gas chromatography (GC) methods. The 
effects of different operational parameters including the $\mathrm{MeOH}$-to-PFAD molar ratio, catalyst dosage, reaction temperature, and agitation speed were examined using a one-factor-at-a-time approach [28]. All the experiments were carried out in duplicate, and the average values are shown in the figures.

\subsubsection{Analysis}

Sample titration was carried out using an alcoholic potassium hydroxide solution to determine the amount of unconverted PFAD in terms of its acid value [14]. Instrumental analysis of the optimized sample was performed using a gas chromatograph (Clarus 580, PerkinElmer) equipped with a flame ionization detector along with a BPX70 capillary column $(25 \mathrm{~m} \times 0.25 \mathrm{~mm}$ with $0.25 \mu \mathrm{m}$ film thickness). The sample was diluted in hexane and injected with $0.2 \mu \mathrm{L}$ volume. Nitrogen gas was used as a carrier gas. The injector and detector temperatures were set at $220^{\circ} \mathrm{C}$ and $240{ }^{\circ} \mathrm{C}$, respectively. The oven temperature was programmed in the following steps: 70 ${ }^{\circ} \mathrm{C}$ for $2 \mathrm{~min} ; 10^{\circ} \mathrm{C} / \mathrm{min}$ to $190^{\circ} \mathrm{C}$; then $5^{\circ} \mathrm{C} / \mathrm{min}$ to $240{ }^{\circ} \mathrm{C}$ and held for $10 \mathrm{~min}$. The percentage conversion of PFAD was determined by Eq. 3.

Conversion $(\%)=\frac{A V_{i}-A V_{t}}{A V_{i}} \times 100$,

where $A V_{i}$ is the initial acid value (without the addition of $M N P-C A L B_{E X}$ ) and $A V_{t}$ is the acid value at time $t$ (with the addition of MNP-CALB $B_{E X}$ ) of the esterified reaction mixture.

\subsubsection{Reusability of the biocatalyst}

The reusability of the magnetic biocatalyst was evaluated for the esterification of PFAD with $\mathrm{MeOH}$ in a batch reactor at the optimized reaction parameters. After completion of the esterification reaction, immobilized lipase was separated out using a magnet and washed with $n$-hexane. The washed magnetic biocatalyst was reused in the next cycle. The conversion of the first cycle was set as $100 \%$, and residual conversion in subsequent cycles was estimated accordingly.

\section{Results and discussion}

\subsection{Characterization of MNP-CALB ${ }_{\mathrm{EX}}$}

The MNP-CALB $B_{E X}$ biocatalyst was characterized by TEM, $B E T$, and FTIR, while activity was assayed using hydrolysis of pNPA, and immobilization efficiency was evaluated by the Bradford assay.

The FTIR spectra of MNP-NH ${ }_{2}, M_{N P}-C_{A L B}$, and CALB ${ }_{E X}$ are shown in Fig. $1 \mathrm{a}-\mathrm{c}$. The absorption band at $581 \mathrm{~cm}^{-1}$ and $575 \mathrm{~cm}^{-1}$ is a characteristic peak of $\mathrm{F}_{3} \mathrm{O}_{4}$ MNPs, which indicates the stretching vibration of $\mathrm{Fe}-\mathrm{O}$ [29]. For MNP-NH ${ }_{2}$ (Fig. 1a), the peaks observed at $3170 \mathrm{~cm}^{-1}$ and $3113 \mathrm{~cm}^{-1}$, and $1686 \mathrm{~cm}^{-1}$ are mainly attributed to stretching and bending vibrations of the primary amine $\left(-\mathrm{NH}_{2}\right)$, respectively [22]. In Fig. $1 \mathrm{~b}$, the absorption peaks at $1640 \mathrm{~cm}^{-1}$ and $1036 \mathrm{~cm}^{-1}$ correspond to the characteristic peaks of pure lipase $\left(\mathrm{CALB}_{\mathrm{EX}}\right)[30]$ which were observed at $1630 \mathrm{~cm}^{-1}$ and $1075 \mathrm{~cm}^{-1}$ in the FTIR spectrum of immobilized lipase (MNP-CALB ${ }_{E X}$ ) (Fig. 1C). Broad absorption peaks of the hydroxyl group appear at $3392 \mathrm{~cm}^{-1}$ and $3321 \mathrm{~cm}^{-1}$ (Fig. $1 b-c$ ) due to stretching vibrations.

TEM analysis was carried out to determine the particle size and morphology of MNP-CALB $\mathrm{Ex}_{\mathrm{X}}$. The magnified TEM images of magnetic nanoparticles are shown in Fig. 2. The TEM image at magnification of $\times 200,000$ revealed that the magnetic $\mathrm{Fe}_{3} \mathrm{O}_{4}$ nanoparticles were almost spherical or ellipsoid, with particle size of 10-20 nm.

BET analysis of $\mathrm{Fe}_{3} \mathrm{O}_{4}$ MNPs was carried out to determine the specific surface area and pore volume, which revealed values of $143.26 \mathrm{~m}^{2} / \mathrm{g}$ and $0.18 \mathrm{~cm}^{3} / \mathrm{g}$, respectively. A large surface area aids in the anchoring of a large amount of lipase on its surface. The lipase loading found in the present work was $56 \mathrm{mg} / \mathrm{g}$ of support, which is much higher than that for enzyme immobilized on a silica nanoparticle support ( $36 \mathrm{mg} / \mathrm{g}$ support) reported in the literature [20]. The lipase immobilization efficiency was calculated from Eq. 2 and was found to be $85 \%$.

\subsection{Effect of biocatalyst loading}

Industrial-scale enzymatic biodiesel production cost is largely affected by the higher cost of the enzyme. Also, enzyme loading has a significant impact on the conversion of PFAD to biodiesel. Therefore, it is necessary to optimize the amount of catalyst loading to reduce production cost while achieving maximum conversion. Hence, the effect of catalyst (MNP-CALB $B_{E X}$ ) loading on the percentage PFAD conversion was studied in the range of $4-10 \mathrm{wt} \%$ while other parameters including temperature, molar ratio, and agitation speed were kept constant, and the results obtained are depicted in Fig. 3. It can be observed that the conversion of PFAD increased from $54.46 \%$ at $4 \mathrm{wt} \%$ dose of MNP-CALB ${ }_{E X}$ to $82.74 \%$ at $8 w t \%$ of MNP-CALB (lipase content $0.45 \mathrm{wt} \%)$. As the reaction occurred at the interface of the biocatalyst and reactants, increasing the biocatalyst dose increased the interfacial area for the interaction between catalyst and reactants to form an enzyme-substrate complex that was then transformed into the product 
Fig. 1 FT-IR spectra of MNP$\mathrm{NH}_{2}(\mathbf{a})$, free lipase $\left(C A L B_{E X}\right)(\mathbf{b})$, and $\mathrm{MNP}_{-\mathrm{CALB}_{\mathrm{EX}}}(\mathbf{c})$
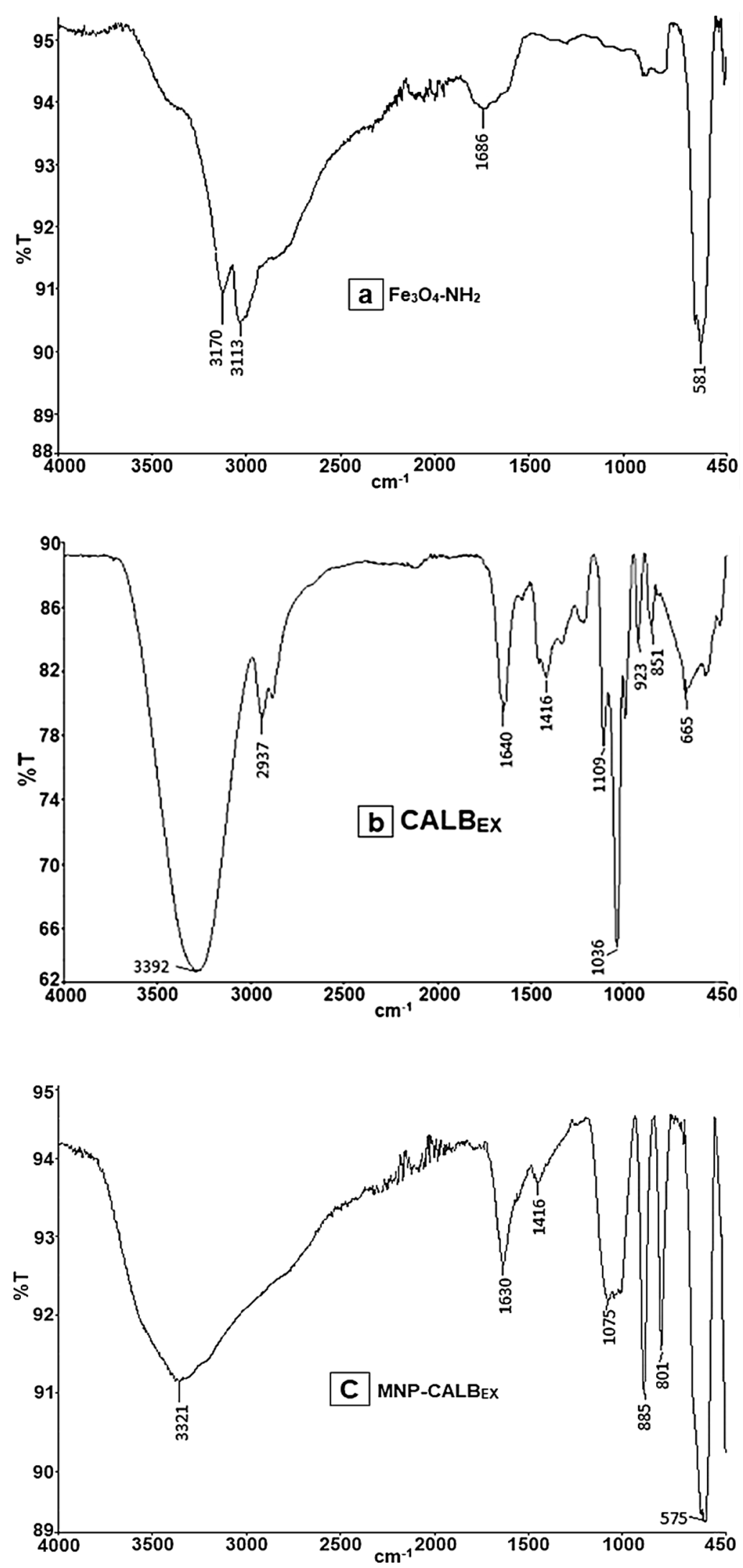
Fig. 2 TEM images of MNP-

$\mathrm{CALB}_{\mathrm{EX}}$ at $\times 40,000$ and

$\times 200,000$ magnification
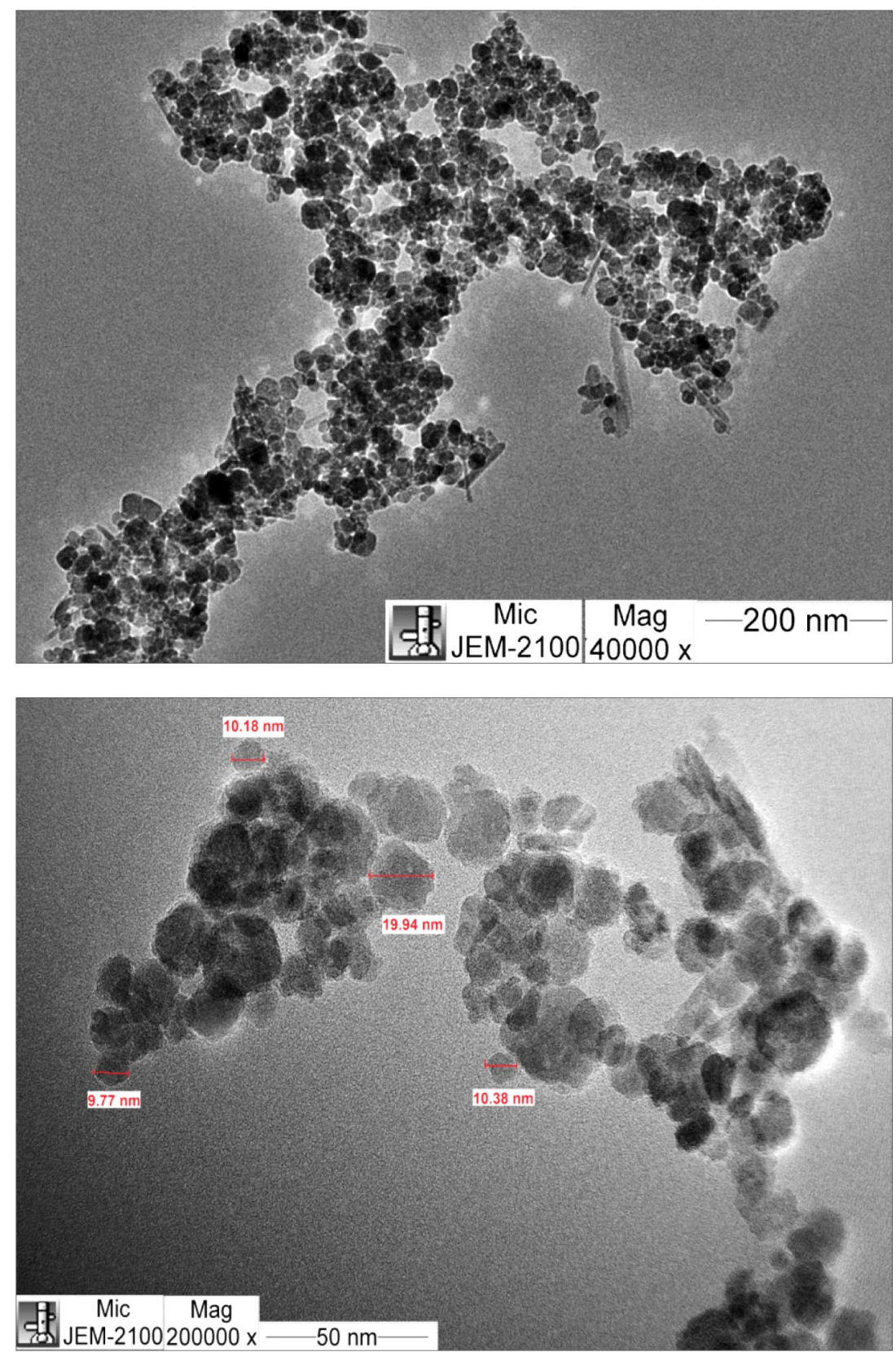

and enzyme. Gharat and Rathod [31] also reported that higher biocatalyst loading enhanced the formation of the enzyme-substrate complex due to an increase in the active catalytic sites, and thus the conversion increased.

However, a further increase in catalyst loading (10 wt\%) showed an insignificant increase in conversion. This may be due to the saturation of the interface with enzyme, and hence a further increase in enzyme loading showed no enhancement in conversion. Hence, $8 \mathrm{wt} \%$ was considered as optimum MNP-CALB $\mathrm{EX}_{\mathrm{E}}$ loading. Adewale et al. [32] investigated the effect of enzyme concentration on the production of biodiesel from waste tallow. They reported that an increase in enzyme concentration from $4 \mathrm{wt} \%$ to $6 \mathrm{wt} \%$ resulted in an increase in biodiesel yield from $60 \%$ to $85.6 \%$, while a further increase in enzyme concentration (8 wt\%) showed no difference in yield. Similarly, Pedro et al. [33] studied the influence of enzyme (Novozym 435) loading on ester content by varying the amount of catalyst from $1 \mathrm{wt} \%$ to $9 \mathrm{wt} \%$. The highest ester content of $73 \%$ was reported at enzyme loading of $9 \mathrm{wt} \%$.

\section{SN Applied Sciences}




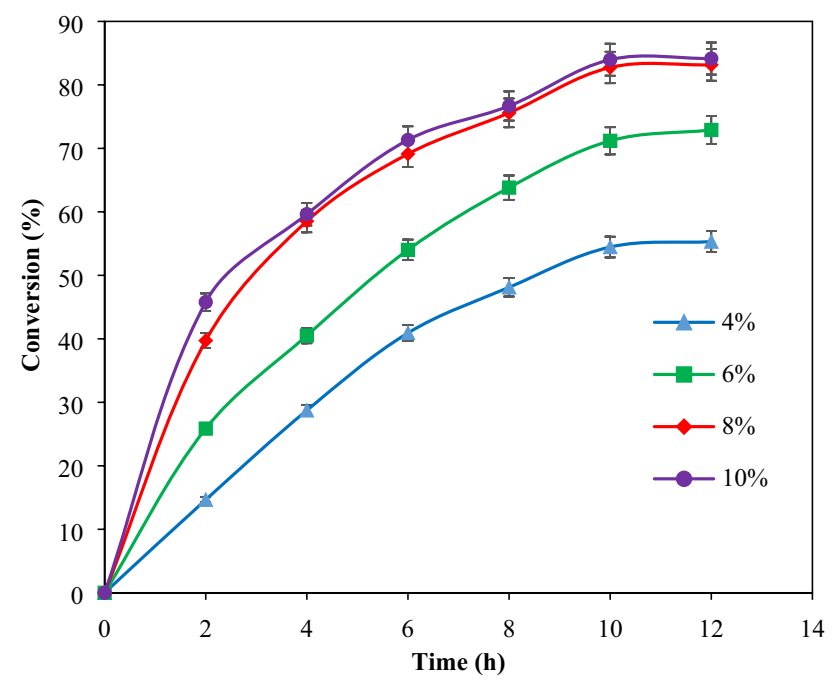

Fig. 3 Effect of biocatalyst loading on the conversion of PFAD at a temperature of $50{ }^{\circ} \mathrm{C}, \mathrm{MeOH}$-to-PFAD molar ratio of 1.6:1, agitation speed of $150 \mathrm{rpm}$

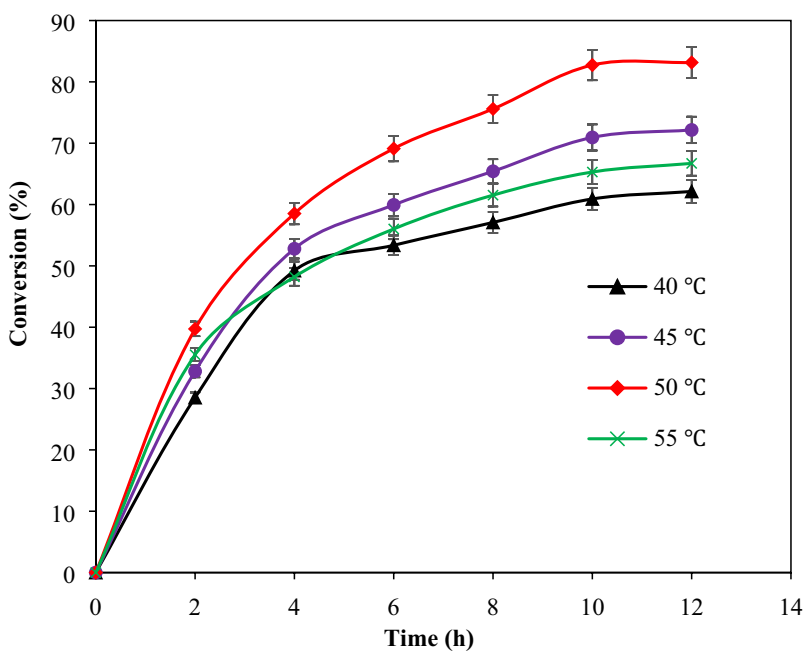

Fig. 4 Effect of temperature on the conversion of PFAD at 8 wt $\%$ biocatalyst, $\mathrm{MeOH}$-to-PFAD molar ratio of 1.6:1, agitation speed of $150 \mathrm{rpm}$

\subsection{Effect of temperature}

Reaction temperature is an important parameter for biocatalyzed reaction, and enhances the substrate interaction by decreasing the viscosity and increasing collisions [34]. In general, the reaction rate increases with increased temperature, but because biocatalyzed reactions are temperature-sensitive, high temperature can hamper enzyme activity. Therefore, the influence of temperature on enzyme-catalyzed esterification of PFAD was examined in the range of $40-55^{\circ} \mathrm{C}$, and the results are depicted in Fig. 4. It can be seen that the percentage conversion increased with an increase in the temperature from 40 ${ }^{\circ} \mathrm{C}$ to $50^{\circ} \mathrm{C}$. This increase in conversion may be due to an increase in the number of collisions between the reactant and biocatalyst, thus promoting the formation of a substrate-enzyme complex and consequent increase in the conversion of PFAD.

However, when the temperature was increased to $55^{\circ} \mathrm{C}$, the conversion of PFAD decreased, owing to the denaturation of lipase molecules. From a cost perspective, the process which occurs at the lowest possible temperature and gives maximum conversion in a short time is considered the best process. Charpe and Rathod [35] studied the effect of temperature on lipase-catalyzed biodiesel production from waste frying oil and reported that the percent conversion decreased at $55^{\circ} \mathrm{C}$ due to deactivation of lipase. A similar effect of temperature on esterification of palmitic acid using Novozym 435 biocatalyst was reported by Syamsul et al. [36]. In their study, maximum conversion was obtained at $40^{\circ} \mathrm{C}$, and a decrease in conversion was observed after $50^{\circ} \mathrm{C}$. Therefore, $50^{\circ} \mathrm{C}$ was established as the optimum temperature for the esterification of PFAD in the present study.

\subsection{Effect of molar ratio}

The esterification reaction is a reversible reaction as the reaction proceeds, ester and water are formed as product and by-product, respectively; the esters are then hydrolyzed by the water into acid and alcohol. Therefore, an excess of alcohol is required to shift the equilibrium towards the product side, in addition to that the excess alcohol acts as a solvent to reduce the viscosity of the

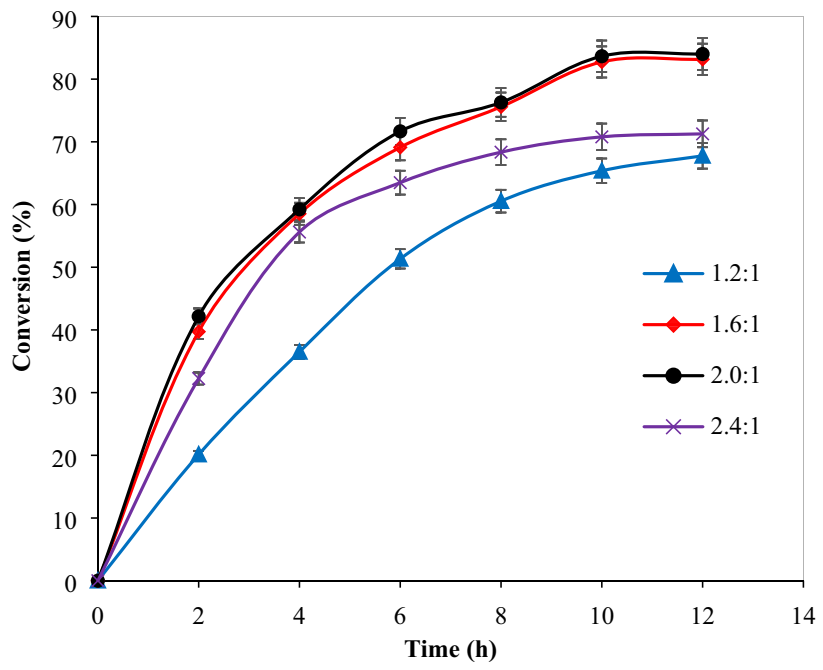

Fig. 5 Effect of molar ratio on the conversion of PFAD at 8 wt $\%$ biocatalyst loading, esterification temperature of $50{ }^{\circ} \mathrm{C}$, and agitation speed of $150 \mathrm{rpm}$ 
PFAD and hence the diffusion resistance between the heterogeneous biocatalyst and reactant. On the other hand, the use of excess alcohol increases biodiesel production cost, so it is necessary to optimize the molar ratio to achieve the highest possible conversion with minimal use of alcohol.

In this regard, the effect of the molar ratio (MeOH-toPFAD) was studied in the range of 1.2:1 to 2.4:1. Figure 5 shows that the conversion of the PFAD was increased for molar ratios of 1.2:1 (65.38\%) and 1.6:1 (82.74\%), while the 2:1 molar ratio showed a marginal increase in conversion. When the molar ratio was increased to $2.4: 1$, the conversion of PFAD decreased significantly. Yu et al. [37] reported similar results for the esterification of conjugated linoleic acid using immobilized lipase. As the molar ratio of alcohol increased from 0.5:1 to 1:1, conversion increased from $43.2 \%$ to $54.9 \%$. However, with a further increase in the molar ratio to $2: 1$, conversion decreased to $38.1 \%$. This decrease may be attributed to the inhibitory effect of alcohol (MeOH or ethanol) in higher amounts [37, 38]. Zhong et al. [39] found that short-chain alcohols, especially $\mathrm{MeOH}$, are toxic to lipase, as esterification of oleic acid with $\mathrm{MeOH}$ yielded the lowest conversion $(<20 \%)$. Lotti et al. [40] reported that a higher concentration of short-chain alcohols might lead to enzyme unfolding and subsequent non-reversible deactivation. Thus, a $\mathrm{MeOH}-$ to-PFAD molar ratio of 1.6:1 was considered suitable to obtain maximum conversion by considering the cost and inhibitory action of $\mathrm{MeOH}$ on the biocatalyst.

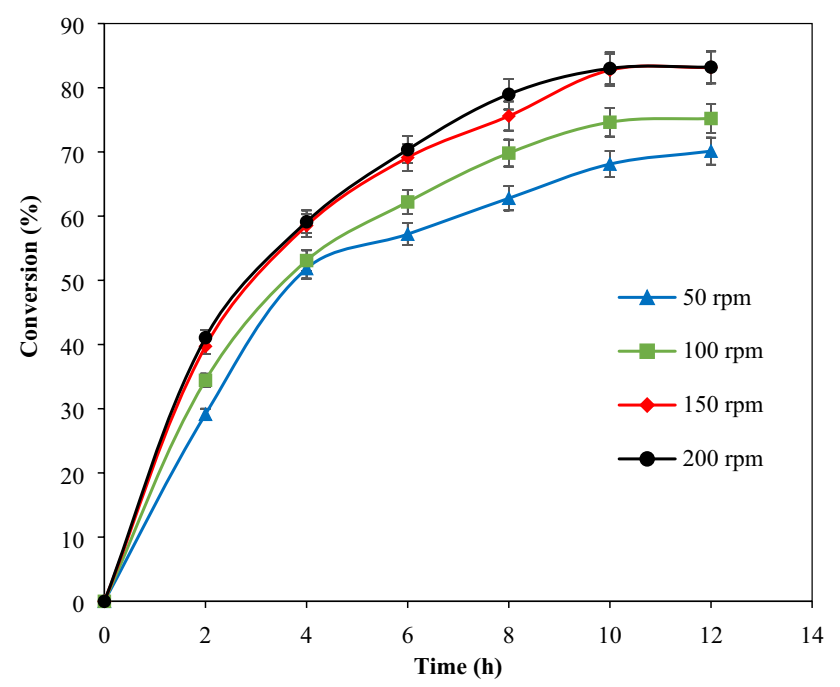

Fig. 6 Effect of agitation speed on the conversion of PFAD at biocatalyst loading of $8 \mathrm{wt} \%$, esterification temperature of $50{ }^{\circ} \mathrm{C}$, and molar ratio of $1.6: 1$

\subsection{Effect of agitation speed}

Mass transfer is a major hurdle in heterogeneous biocatalyzed reactions due to the diffusion resistance that arises between the immobilized biocatalyst and the liquid substrate. This limitation can be minimized or overcome by agitation of the heterogeneous system. However, agitation at a higher speed consumes more energy, which adds to biodiesel production costs. Therefore, the effect of agitation speed on the conversion of PFAD into FAME was examined at different rpm (50-200), and the results are depicted in Fig. 6 . The figure shows that as the agitation speed increased from 50 to $150 \mathrm{rpm}$, the percentage conversion increased from $68.10 \%$ to $82.74 \%$. The high agitation speed dispersed the immobilized enzyme (MNP$\left(A L B_{E X}\right)$ homogeneously in the reaction medium, enabling the reactant molecules to more easily access the surface of the biocatalyst.

However, a further increase in the agitation speed (200 rpm) exhibited no significant increase in conversion. A similar trend was reported by Kumari et al. [41] for biodiesel production from Jatropha oil. In their study, enzymatic biodiesel production increased with an increase in the agitation speed from 100 to $200 \mathrm{rpm}$, but a further increase in agitation speed did not affect the conversion percentage of Jatropha oil. Considering the maximum PFAD conversion and cost, $150 \mathrm{rpm}$ was considered as an optimal value.

\subsection{Reusability of the MNP- CALB ${ }_{\mathrm{EX}}$}

The immobilization of lipase on magnetic nanoparticles is beneficial for the recovery of the biocatalyst for utilization in successive batches. The reusability of the immobilized

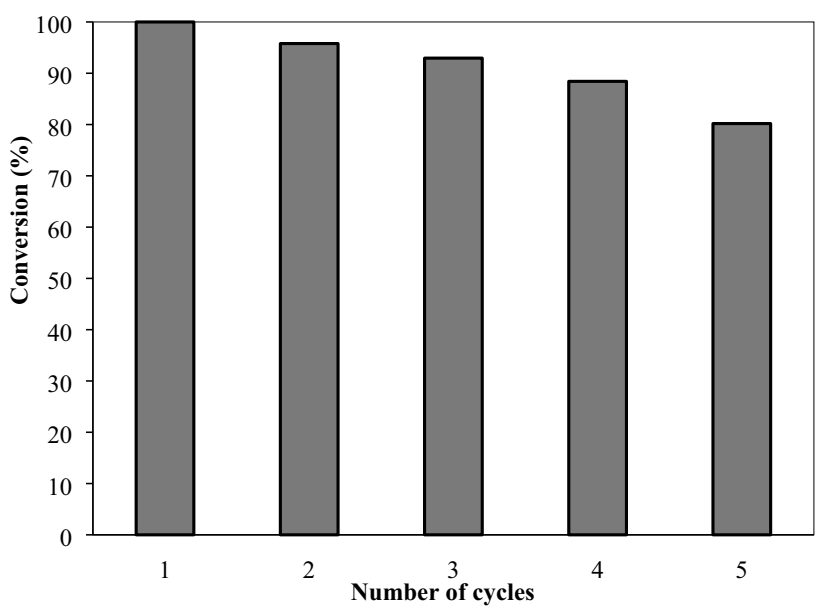

Fig. 7 Reusability of MNP- CALB $_{E X}$ biocatalyst at PFAD-to-MeOH molar ratio of $1.6: 1$, biocatalyst loading of $8 \mathrm{wt} \%$, reaction temperature of $50^{\circ} \mathrm{C}$, and agitation speed of $150 \mathrm{rpm}$ 
lipase is an essential factor in the cost-effective esterification of PFAD to produce biodiesel.

The reusability of the magnetic biocatalyst was investigated at optimized operating conditions, i.e. PFAD-to$\mathrm{MeOH}$ molar ratio of $1.6: 1$, biocatalyst loading of $8 \mathrm{wt} \%$, agitation speed of $150 \mathrm{rpm}$, and temperature of $50^{\circ} \mathrm{C}$ for a reaction time of $10 \mathrm{~h}$. The reusability was tested up to five cycles, and the results are illustrated in Fig. 7. It can be seen that after each cycle, the residual activity of the biocatalyst was decreased. In the fifth cycle, residual conversion of $80.19 \%$ was observed. The drop in the residual conversion may be due to the denaturation of lipase after prolonged use [42].

\subsection{Comparison of catalyst activity of MNP- CALB $_{\mathrm{EX}}$ with Amberlyst-15}

A comparative study was carried out to determine the efficacy of the synthesized biocatalyst with commercial Amberlyst-15 (strongly acidic ion-exchange resin). The esterification reaction was performed under (biocatalyzed) optimized reaction conditions as follows: $\mathrm{MeOH}$-to-PFAD molar ratio of 1.6:1, catalyst loading of $8 \mathrm{wt} \%$, reaction temperature of $50{ }^{\circ} \mathrm{C}$, agitation speed of $150 \mathrm{rpm}$, and reaction time of $10 \mathrm{~h}$. Conversion of $31.56 \%$ was obtained, which indicates that MNP-CALB $B_{E X}$ was a more active catalyst in the transformation of PFAD into FAME as compared to commercially available Amberlyst-15, with MNP-CALB ${ }_{E X}$ achieving a 2.6-fold improvement over the Amberlyst-15 catalyst. The higher conversion in the case of MNP-CALB ${ }_{E X}$ may be due to the availability of more active sites because of the large surface area $\left(143.26 \mathrm{~m}^{2} / \mathrm{g}\right)$. Therefore, it was concluded that the current magnetic biocatalyst is more efficient than commercially available Amberlyst- 15 under the above-reported reaction conditions.

\section{Conclusion}

In this study, immobilized lipase on $\mathrm{Fe}_{3} \mathrm{O}_{4}$ MNPs was effectively utilized to esterify PFAD to produce biodiesel. Also, $82.74 \%$ can be considered as good conversion as the used biocatalyst contain only $0.45 \mathrm{wt} \%$ lipase.

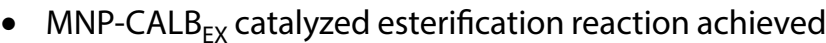
$82.74 \%$ conversion at optimized reaction conditions, i.e, molar ratio of $1.6: 1$, biocatalyst loading of $8 \mathrm{wt} \%$ ( $0.45 \mathrm{wt} \%$ lipase contain), esterification temperature of $50^{\circ} \mathrm{C}$, and agitation speed of $150 \mathrm{rpm}$.
- Under the above mentioned conditions, the commercial Amberlyst-15 catalyst provided only $31.56 \%$ conversion over a reaction time of $10 \mathrm{~h}$.

- Immobilization efficiency was found to be $85 \%$, which was provided with $56 \mathrm{mg}$ of lipase/g of support.

- The immobilized biocatalyst, MNP-CALB $\mathrm{EX}_{\text {, }}$ was recycled for up to five cycles, with residual conversion of $80.19 \%$ in the fifth cycle.

Acknowledgments The authors would like to acknowledge the University Grants Commission (UGC), Grant No. F.5-64/2007 (Basic Scientific Research, BSR), of India for the research financial assistance.

\section{Compliance with ethical standards}

Conflict of interest The authors declare that they have no conflict of interest.

\section{References:}

1. Gupta AR, Rathod VK (2019) Solar radiation as a renewable energy source for the biodiesel production by esterification of palm fatty acid distillate. Energy 182:795-801

2. Madhu D, Chavan SB, Singh V, Singh B, Sharma YC (2016) An economically viable synthesis of biodiesel from a crude Millettia pinnata oil of Jharkhand, India as feedstock and crab shell derived catalyst. Bioresour Technol 214:210-217

3. Sharma YC, Singh V (2017) Microalgal biodiesel: A possible solution for India's energy security. Renew Sustain Energy Rev 67:72-88

4. Goswami K, Hazarika A (2016) Supply chain network of Jatropha based biodiesel industry in North East India. Sustain Prod Consum 6:38-50

5. BP Statistical Review of World Energy About this review (2016). https://www.bp.com/en/global/corporate/energy-econo mics/statistical-review-of-world-energy.html. Accessed 30 August 2019

6. ET Energyworld (2018). https://energy.economictimes.india times.com/news/oil-and-gas/india-records-lowest-crude-oilproduction-in-seven-years/63640955. Accessed 3 December 2019

7. The Economic Times (2018). https://economictimes.indiatimes .com/industry/energy/oil-gas/indias-oil-import-bill-to-jumpby-25-in-fy18/articleshow/63464408.cms. Accessed 18 July 2019

8. Black MJ, Whittaker C, Hosseini SA, Diaz-Chavez R, Woods J, Murphy RJ (2011) Life Cycle Assessment and sustainability methodologies for assessing industrial crops, processes and end products. Ind Crops Prod 34:1332-1339

9. National Policy on Biofuel (2018). https://petroleum.nic.in/ national-policy-biofuel-2018-0. Accessed 8 May 2019

10. Gaikwad ND, Gogate PR (2015) Synthesis and application of carbon based heterogeneous catalysts for ultrasound assisted biodiesel production. Green Process Synth 4:17-30

11. Atabani $A E$, Silitonga AS, Ong HC, Mahlia TMI, Masjuki $H H_{\text {, }}$ Badruddin IA, Fayaz H (2013) Non-edible vegetable oils: A critical evaluation of oil extraction, fatty acid compositions, biodiesel production, characteristics, engine performance and emissions production. Renew Sustain Energy Rev 18:211-245 
12. Demirbas A, Bafail A, Ahmad W, Sheikh M (2016) Biodiesel production from non-edible plant oils. Energy Explor Exploit 34:290-318

13. Neste (2016). https://www.neste.com/corporate-info/susta inability/sustainable-supply-chain/pfad-residue-palm-oilrefining-process. Accessed 15 November 2019

14. Gupta AR, Chiplunkar PP, Pratap AP, Rathod VK (2020) Esterification of Palm Fatty Acid Distillate for FAME Synthesis Catalyzed by Super-Acid Catalyst HCISO3-ZrO2. Waste and Biomass Valorization. https://doi.org/10.1007/s12649-020-00949-y

15. Nongbe MC, Ekou T, Ekou L, Yao KB, Le Grognec E, Felpin FX (2017) Biodiesel production from palm oil using sulfonated graphene catalyst. Renew Energy 106:135-141

16. Tran TTV, Kaiprommarat $S$, Kongparakul $S$, Reubroycharoen $P$, Guan G, Nguyen MH, Samart C (2016) Green biodiesel production from waste cooking oil using an environmentally benign acid catalyst. Waste Manag 52:367-374

17. Vieira SS, Magriotis ZM, Santos NAV, Saczk AA, Hori CE, Arroyo PA (2013) Biodiesel production by free fatty acid esterification using lanthanum (La3+) and HZSM-5 based catalysts. Bioresour Technol 133:248-255

18. Guldhe A, Singh B, Mutanda T, Permaul K, Bux F (2015) Advances in synthesis of biodiesel via enzyme catalysis: Novel and sustainable approaches. Renew Sustain Energy Rev 41:1447-1464

19. Fan X, Niehus X, Sandoval G (2012) Lipases as Biocatalyst for Biodiesel Production. In: Sandoval G (ed) Lipases and Phospholipases: Methods and Protocols. Springer Science+Business Media, New York, pp 471-483

20. Babaki M, Yousefi M, Habibi Z, Mohammadi M, Yousefi P, Mohammadi J, Brask J (2016) Enzymatic production of biodiesel using lipases immobilized on silica nanoparticles as highly reusable biocatalysts: Effect of water, t-butanol and blue silica gel contents. Renew Energy 91:196-206

21. Macario A, Verri F, Diaz U, Corma A, Giordano G (2013) Pure silica nanoparticles for liposome/lipase system encapsulation: Application in biodiesel production. Catal Today 204:148-155

22. Miao C, Yang L, Wang Z, Luo W, Li H, Lv P, Yuan Z (2018) Lipase immobilization on amino-silane modified superparamagnetic Fe304nanoparticles as biocatalyst for biodiesel production. Fuel 224:774-782

23. Xie W, Wang J (2014) Enzymatic production of biodiesel from soybean oil by using immobilized lipase on Fe304/Poly(styrenemethacrylic acid) magnetic microsphere as a biocatalyst. Energy Fuels 28:2624-2631

24. Nadar SS, Rathod VK (2018) Encapsulation of lipase within metal-organic framework (MOF) with enhanced activity intensified under ultrasound. Enzyme Microb Technol 108:11-20

25. Wang X, Dou P, Zhao P, Zhao C, Ding Y, Xu P (2009) Immobilization of lipases onto magnetic Fe3O4nanoparticles for application in biodiesel production. Chemsuschem 2:947-950

26. Abraham RE, Verma ML, Barrow CJ, Puri M (2014) Suitability of magnetic nanoparticle immobilised cellulases in enhancing enzymatic saccharification of pretreated hemp biomass. Biotechnol Biofuels 7:1-12
27. Nadar SS, Gawas SD, Rathod VK (2016) Self-assembled organicinorganic hybrid glucoamylase nanoflowers with enhanced activity and stability. Int J Biol Macromol 92:660-669

28. Gupta AR, Rathod VK (2018) Calcium diglyceroxide catalyzed biodiesel production from waste cooking oil in the presence of microwave: Optimization and kinetic studies. Renew Energy 121:757-767

29. Zhang LY, Zhu XJ, Sun HW, Chi GR, Xu JX, Sun YL (2010) Control synthesis of magnetic Fe3O4-chitosan nanoparticles under UV irradiation in aqueous system. Curr Appl Phys 10:828-833

30. Ali Z, Tian L, Zhang B, Ali N, Khan M, Zhang Q (2017) Synthesis of fibrous and non-fibrous mesoporous silica magnetic yolk-shell microspheres as recyclable supports for immobilization of Candida rugosa lipase. Enzyme Microb Technol 103:42-52

31. Gharat N, Rathod VK (2013) Ultrasound assisted enzyme catalyzed transesterification of waste cooking oil with dimethyl carbonate. Ultrason Sonochem 20:900-905

32. Adewale P, Dumont MJ, Ngadi M (2015) Enzyme-catalyzed synthesis and kinetics of ultrasonic-assisted biodiesel production from waste tallow. Ultrason Sonochem 27:1-9

33. Pedro KCNR, Parreira JM, Correia IN, Henriques CA, Langone MAP (2018) Enzymatic biodiesel synthesis from acid oil using a lipase mixture. Quim Nova 41:284-291

34. Badgujar KC, Bhanage BM (2014) Application of lipase immobilized on the biocompatible ternary blend polymer matrix for synthesis of citronellyl acetate in non-aqueous media: Kinetic modelling study. Enzyme Microb Technol 57:16-25

35. Charpe TW, Rathod VK (2011) Biodiesel production using waste frying oil. Waste Manag 31:85-90

36. Syamsul KMW, Salina MR, Siti SO, Hanina MN, Basyaruddin MAR, Jusoff K (2010) Green Synthesis of Lauryl Palmitate via LipaseCatalyzed Reaction. World Appl Sci J 11:401-407

37. Yu WH, Tong DS, Fang M, Shao P, Zhou CH (2015) Immobilization of Candida rugosa lipase on MSU-H type mesoporous silica for selective esterification of conjugated linoleic acid isomers with ethanol. J Mol Catal B-Enzym 111:43-50

38. Jeon DJ, Yeom SH (2011) Comparison of methods for preventing methanol inhibition in enzymatic production of biodiesel. Korean J Chem Eng 28:1420-1426

39. Zhong H, Fang Z, Zou B, Li X, Ouyang P, Guo K (2013) Studies on the lipase-catalyzed esterification of alkyl oleates in solvent-free systems. J Mol Catal B-Enzym 90:114-117

40. Lotti M, Pleiss J, Valero F, Ferrer P (2015) Effects of methanol on lipases: Molecular, kinetic and process issues in the production of biodiesel. Biotechnol J 10:22-30

41. Kumari A, Mahapatra P, Garlapati VK, Banerjee R (2009) Enzymatic transesterification of Jatropha oil. Biotechnol Biofuels 2:1-7

42. Gawas SD, Jadhav SV, Rathod VK (2016) Solvent Free Lipase Catalysed Synthesis of Ethyl Laurate: Optimization and Kinetic Studies. Appl Biochem Biotechnol 180:1428-1445

Publisher's Note Springer Nature remains neutral with regard to jurisdictional claims in published maps and institutional affiliations. 